\title{
Description of Roseateles aquatilis sp. nov. and Roseateles terrae sp. nov., in the class Betaproteobacteria, and emended description of the genus Roseateles
}

\author{
Correspondence \\ Jorge Lalucat \\ jlalucat@uib.es
}

\author{
Margarita Gomila, ${ }^{1}$ Botho Bowien, ${ }^{2}$ Enevold Falsen, ${ }^{3}$ Edward R. B. Moore ${ }^{3}$ \\ and Jorge Lalucat ${ }^{1}$
${ }^{1}$ Área Microbiologia, Departament de Biologia, Universitat de les Illes Balears, and Institut Mediterrani d'Estudis Avançats (CSIC-UIB), 07122 Palma de Mallorca, Illes Balears, Spain Göttingen, 37077 Göttingen, Germany
${ }^{3}$ CCUG, Culture Collection, Department of Clinical Bacteriology, University of Göteborg, 41346 Göteborg, Sweden \\ ${ }^{2}$ Abt. Molekularphysiologie, Institut für Mikrobiologie und Genetik, Georg-August-Universität
}

\begin{abstract}
Three strains of aerobic Gram-negative bacilli, two isolated from industrial water and freshwater (strains CCUG $48205^{\top}$ and CCUG 52220) and the third from soil (strain CCUG $52222^{\top}$ ), were analysed phenotypically and genotypically to clarify their taxonomic classification. 16S rRNA gene sequence analysis revealed that the three strains were located on the same phylogenetic branch, closely related to Roseateles depolymerans, the only recognized species in the genus. DNA-DNA hybridization studies, analyses of fatty acid contents, and physiological and biochemical tests supported the proposal of two novel species, Roseateles aquatilis sp. nov. (type strain, CCUG $48205^{\top}=$ CECT $7248^{\top}$ ) and Roseateles terrae sp. nov. (type strain, CCUG $52222^{\top}=$ CECT $7247^{\top}$ ).
\end{abstract}

The genera Aquabacterium (Kalmbach et al., 1999), Ideonella (Malmqvist et al., 1994), Rubrivivax (Willems et al., 1991), Roseateles (Suyama et al., 1999), Azohydromonas (Xie \& Yokota, 2005), Mitsuaria (Amakata et al., 2005) and Pelomonas (Xie \& Yokota, 2005; Gomila et al., 2007) are phylogenetically closely related to the Sphaerotilus-Leptothrix group. These genera form the Rubrivivax line of descent, which is associated with the family Comamonadaceae (Wen et al., 1999). Willems \& Gillis (2001) consider these genera to be of incertae sedis within the family Comamonadaceae. The relative branching order of most species within the Rubrivivax group is difficult to determine, mainly because of the limited number of variable positions available for estimating phylogenetic distance values (Spring, 2001).

Abbreviations: ITS, internally transcribed spacer; PHC, poly(hexamethylene carbonate).

The GenBank/EMBL/DDBJ accession numbers for the 16S rRNA, ITS1, nifH and puf gene sequences determined in this study are AM501443-AM501446, AM501462, AM501479 and AM501480, and AM773545-AM773547, respectively.

Carbon source utilization data (Biolog), DNA-DNA hybridization values and a $16 \mathrm{~S}$ rRNA gene sequence matrix are available as supplementary tables with the online version of this paper.
Roseateles depolymerans $61 \mathrm{~A}^{\mathrm{T}} \quad\left(=\mathrm{CCUG} 52219^{\mathrm{T}}=\mathrm{DSM}\right.$ $11813^{\mathrm{T}}$ ), which is closely related to species of the genera Mitsuaria and Pelomonas, was isolated in 1998 from river water and described in 1999 as the first bacteriochlorophyll a-containing, obligate aerobe belonging to the Betaproteobacteria. The strain was isolated originally as a degrader of poly(hexamethylene carbonate) (PHC) and is considered to be an aerobic phototroph (Suyama et al., 1999). Since 2005, three novel strains (CCUG $48205^{\mathrm{T}}$, CCUG 52220 and CCUG $52222^{\mathrm{T}}$ ) have been isolated from different sources, including industrial water, freshwater and soil, and were identified provisionally as 'Roseateles depolymerans-like' organisms. The present study was undertaken to characterize and determine the taxonomic positions of these organisms. The data demonstrated that strains CCUG $48205^{\mathrm{T}}$ and CCUG $52222^{\mathrm{T}}$ should be classified as representing two novel species, with the names Roseateles aquatilis sp. nov. and Roseateles terrae sp. nov., respectively.

The reference strains used in this study included Pelomonas saccharophila CCUG $32988^{\mathrm{T}}$, Pelomonas aquatica CCUG $52575^{\mathrm{T}}$, Pelomonas puraquae CCUG $52769^{\mathrm{T}}$, Mitsuaria chitosanitabida IAM $14711^{\mathrm{T}}$ and Roseateles depolymerans CCUG $52219^{\mathrm{T}}$, as well as Roseateles depolymerans strain CCUG 52220, Roseateles sp. strain CCUG $52222^{\mathrm{T}}$ and 
Roseateles depolymerans-like strain CCUG $48205^{\mathrm{T}}$. All of the strains used in this study were cultivated in R2A medium (Reasoner \& Geldreich, 1985), containing $\left(1^{-1}\right)$ : $0.5 \mathrm{~g}$ yeast extract, $0.5 \mathrm{~g}$ acid hydrolysate of casein, $0.5 \mathrm{~g}$ glucose, $0.5 \mathrm{~g}$ starch, $0.3 \mathrm{~g} \mathrm{~K}_{2} \mathrm{HPO}_{4}, 0.3 \mathrm{~g}$ sodium pyruvate, $0.25 \mathrm{~g}$ pancreatic digest of casein, $0.25 \mathrm{~g}$ peptic digest of animal tissue, $0.0492 \mathrm{~g} \mathrm{MgSO}_{4} \cdot 7 \mathrm{H}_{2} \mathrm{O}$, supplemented with $1.5 \%(\mathrm{w} / \mathrm{v})$ agar (Scharlab) for solid medium. The bacteria were incubated for $3-4$ days at $30{ }^{\circ} \mathrm{C}$, if not stated otherwise.

Cell size, morphology and flagella insertion were determined using transmission electron microscopy of cells from the exponential growth phase in R2A broth. A Hitachi model H600 electron microscope was used at $75 \mathrm{kV}$. The samples were negatively stained with phosphotungstic acid ( $1 \% \mathrm{w} / \mathrm{v}, \mathrm{pH} 7.0)$, as described by Lalucat (1988).

The following phenotypic tests were carried out: API 20NE (identification system for Gram-negative, non-enterobacterial rods) and API $50 \mathrm{CH}$, according to the instructions of the manufacturer. Biolog tests were also carried out according to the instructions of the manufacturer. Briefly, the procedure was as follows: a homogeneous suspension of cells grown on plates of trypticase soy agar supplemented with sheep blood was made in the GN/GP inoculating fluid and $150 \mu$ of the suspension was dispensed into each well of a GN microplate, which was then incubated for up to $96 \mathrm{~h}$ at $30{ }^{\circ} \mathrm{C}$. The absorbance values were recorded periodically over a 4 -day period, at $0,4,8,24,48,72$ and $96 \mathrm{~h}$ incubation time, using an automated Microplate reader. Absorbance was measured in dual wavelength mode, at $590 \mathrm{~nm}$ (as respiratory reduction will cause the tetrazolium dye to turn purple and absorb light at $590 \mathrm{~nm}$ ) and at $750 \mathrm{~nm}$ as a second reference wavelength.

Conventional phenotypic tests were done according to the methods of Cowan (1974). Growth rates were determined at different temperatures $\left(4,10,20,30,37\right.$ and $\left.45^{\circ} \mathrm{C}\right)$ in R2A medium, and aerobic autotrophic growth with hydrogen was tested in mineral medium, as described by Aragno \& Schlegel (1992), at different $\mathrm{O}_{2}$ partial pressures. For the detection of photosynthetic pigments, cells were grown in R2A medium, PHC medium (or PHC medium supplemented with Tween 80) or in medium lacking organic carbon as described by Suyama et al. $(1999,2002)$. Lipophilic pigments were extracted from fresh wet cells cultured in the four media, under light or in the dark, using acetone $\left[90 \%(\mathrm{v} / \mathrm{v})\right.$ with $1 \% \mathrm{MgCO}_{3}$ at $4{ }^{\circ} \mathrm{C}$ for $\left.24 \mathrm{~h}\right)$. Absorption spectra were recorded spectrophotometrically (Ultrospec III; Pharmacia LKB) between wavelengths of 360 and $900 \mathrm{~nm}$.

Colonies of strains CCUG $52219^{\mathrm{T}}$ and CCUG 52220 grown on R2A medium for 5 days were $4-5 \mathrm{~mm}$ in diameter, transparent, darker in the centre, circular and flat, with an undulate margin, and smooth and translucent. Strain CCUG $52222^{\mathrm{T}}$ could be differentiated by means of a more mucous appearance of the colonies, which were $4-6 \mathrm{~mm}$ in diameter, less transparent, circular and convex, with an undulate transparent margin. Colonies of strain CCUG $48205^{\mathrm{T}}$ were $4-6 \mathrm{~mm}$ in diameter, clear white, circular and umbonate, with an undulate margin, and translucent. Old colonies showed concentric circles.

Cells were rod-shaped ( $2 \mu \mathrm{m}$ in length), Gram-negative and motile, by means of a single polar flagellum. All strains grew at 20 and $30{ }^{\circ} \mathrm{C}$. None of the strains were able to grow at 4 or $45{ }^{\circ} \mathrm{C}$. The range of growth temperatures is indicated in Table 1. Differential phenotypic characteristics and substrates assimilated or utilized as sole carbon and energy sources are listed in Table 1. Carbon sources utilized in Biolog plates are given in Supplementary Table S1, available in IJSEM Online. Differential phenotypic characteristics obtained in the Biolog test are summarized in Table 2. None of the novel isolates were able to produce pigments when incubated for 1 week in the dark or under light in R2A medium or PHC medium, or in PHC medium supplemented with Tween 80 , as well as in mineral medium.

Gas chromatography of fatty acid methyl esters was performed at CCUG in a highly standardized way, similar to that of the MIDI Sherlock MIS system. Fatty acids were identified and quantified, and the relative amount of each fatty acid in a strain was expressed as a percentage of the total fatty acids in the profile of that strain. The major cellular fatty acids detected in all Roseateles strains analysed (CCUG $48205^{\mathrm{T}}$, CCUG 52219 ${ }^{\mathrm{T}}$, CCUG 52220 and CCUG $52222^{\mathrm{T}}$ ) were cis-9-hexadecanoic and hexadecanoic acids, as indicated in Table 3. Clear differences between Roseateles, Mitsuaria and Pelomonas could be established in the relative amounts of dodecanoic and cis-11octodecanoic acids. The two novel species proposed in the genus Roseateles can be differentiated chemotaxonomically from Roseateles depolymerans by the relative amount of dodecanoic acid.

Genomic DNA was isolated according to the method of Marmur (1961). DNA-DNA hybridizations were performed, in duplicate, using a non-radioactive method as described by Ziemke et al. (1998). Reference DNAs of one strain of each group $\left(P\right.$. saccharophila CCUG $32988^{\mathrm{T}}, P$. puraquae CCUG $52769^{\mathrm{T}}, P$. aquatica CCUG $52575^{\mathrm{T}}, M$. chitosanitabida IAM $14711^{\mathrm{T}}$, Roseateles depolymerans CCUG 52219 ${ }^{\mathrm{T}}$, Roseateles sp. strain CCUG $52222^{\mathrm{T}}$ and Roseateles depolymerans-like strain CCUG $48205^{\mathrm{T}}$ ) were double-labelled with DIG-11-dUTP and biotin-16-dUTP using a Nick Translation kit (Roche). DNA-DNA hybridizations were performed using chromosomal DNA of each type strain as probes against the other strains (see Supplementary Table S2 in IJSEM Online). Strain CCUG 52220 showed $100 \%$ DNA-DNA relatedness to the type strain of Roseateles depolymerans. The levels of DNA-DNA relatedness of strains CCUG $48205^{\mathrm{T}}$ and CCUG $52222^{\mathrm{T}}$ to the other strains were less than $57 \%$, and was $37.1 \%$ between the two strains. This indicates that three different genomic groups can be delineated in the genus Roseateles. 
Table 1. Differential phenotypic characteristics between species of the genera Mitsuaria, Pelomonas and Roseateles

Strains: 1, Roseateles depolymerans CCUG 52219 ${ }^{\mathrm{T}}$; 2, Roseateles depolymerans CCUG 52220; 3, strain CCUG 52222 ${ }^{\mathrm{T}}$ (Roseateles terrae sp. nov.); 4 , strain CCUG $48205^{\mathrm{T}}$ (Roseateles aquatilis sp. nov.); 5, M. chitosanitabida IAM $14711^{\mathrm{T}}$; 6 , P. saccharophila CCUG $32988^{\mathrm{T}}$; 7 , P. puraquae CCUG $52769^{\mathrm{T}}$; 8, P. aquatica CCUG $52575^{\mathrm{T}}$. All strains are oxidase-positive. +, Positive; - , negative; w, weak; v, variable; ND, not determined.

\begin{tabular}{|c|c|c|c|c|c|c|c|c|}
\hline Characteristic & 1 & 2 & 3 & 4 & 5 & 6 & 7 & 8 \\
\hline Flagella & Several, polar ${ }^{\star}$ & One, polar & One, polar & One, polar & One, polar & One, polar & One, polar & One, polar \\
\hline \multicolumn{9}{|l|}{ Growth at: } \\
\hline $10{ }^{\circ} \mathrm{C}$ & + & + & $\mathrm{w}$ & - & + & - & + & - \\
\hline $37{ }^{\circ} \mathrm{C}$ & + & + & + & - & + & - & + & + \\
\hline Autotrophic growth with $\mathrm{H}_{2}$ & - & - & - & - & - & + & + & - \\
\hline Pigment & $+^{*}$ & - & - & - & - & - & - & - \\
\hline Growth on PHC & + & + & $\mathrm{w}$ & + & $\mathrm{w}$ & - & - & - \\
\hline \multicolumn{9}{|l|}{ Amplification of: } \\
\hline$c b b L$ & - & - & - & - & - & + & + & - \\
\hline hox & - & $\mathrm{ND}$ & $\mathrm{ND}$ & $\mathrm{ND}$ & - & $\mathrm{ND}$ & + & - \\
\hline nifH & + & + & + & - & - & + & + & - \\
\hline puf & + & + & + & - & - & - & - & - \\
\hline Catalase & + & + & + & - & - & - & - & - \\
\hline Nitrate reduction & - & - & - & - & + & + & $\mathrm{V}$ & + \\
\hline Urease & + & $\mathrm{w}$ & - & - & - & - & - & - \\
\hline$\beta$-Glucosidase & + & + & + & - & + & + & + & + \\
\hline Gelatin hydrolysis & + & + & + & + & + & - & + & - \\
\hline$\beta$-Galactosidase & + & + & + & - & + & + & + & - \\
\hline \multicolumn{9}{|l|}{ Assimilation of: } \\
\hline D-Glucose & + & + & + & + & + & + & + & - \\
\hline L-Arabinose & + & + & + & - & - & + & + & - \\
\hline D-Mannose & + & + & + & - & - & $\mathrm{V}$ & - & - \\
\hline D-Mannitol & + & + & + & - & - & - & - & - \\
\hline$N$-Acetyl-D-glucosamine & - & - & - & - & - & + & - & - \\
\hline Maltose & + & + & + & + & + & + & + & - \\
\hline Gluconate & + & + & + & + & + & + & - & - \\
\hline Capric acid & $\mathrm{W}$ & - & + & - & + & - & - & - \\
\hline Adipic acid & $\mathrm{W}$ & $\mathrm{w}$ & - & - & - & - & - & - \\
\hline Malic acid & $\mathrm{w}$ & + & $\mathrm{W}$ & + & + & $\mathrm{V}$ & + & - \\
\hline Citrate & $\mathrm{w}$ & + & - & - & + & - & $\mathrm{w}$ & - \\
\hline Phenylacetic acid & - & - & - & - & $\mathrm{w}$ & - & - & - \\
\hline
\end{tabular}

${ }^{\star}$ Data from Suyama et al. (1999).

Table 2. Differential carbon source utilization (Biolog) among the Roseateles strains studied

Strains: 1, Roseateles depolymerans CCUG 52219 ${ }^{\mathrm{T}}$; 2, Roseateles depolymerans CCUG 52220; 3, strain CCUG 52222 ${ }^{\mathrm{T}}$ (Roseateles terrae sp. nov.); 4 , strain CCUG $48205^{\mathrm{T}}$ (Roseateles aquatilis sp. nov.). +, Positive; -, negative.

\begin{tabular}{|c|c|c|c|c|}
\hline Carbon source & 1 & 2 & 3 & 4 \\
\hline $\begin{array}{l}\text { L-Arabinose, D-fructose, D-galactose, D-mannose, D-arabitol, D-mannitol, glycogen, L-pyroglutamic acid, succinic acid } \\
\text { monomethyl ester, urocanic acid }\end{array}$ & + & + & + & - \\
\hline $\begin{array}{l}N \text {-Acetyl-D-galactosamine, D-cellobiose, } \alpha \text {-D-glucose } 1 \text {-phosphate, } \alpha \text {-cyclodextrin, inosine, } \gamma \text {-aminobutyric acid, L- } \\
\text { aspartic acid, citric acid, } \gamma \text {-hydroxybutyric acid, } \alpha \text {-ketobutyric acid, DL-lactic acid, sebacic acid, succinic acid, L-alanine, } \\
\text { L-leucine, L-ornithine, L-proline, L-serine, L-threonine }\end{array}$ & + & + & - & + \\
\hline Malonic acid & + & + & - & - \\
\hline D-Glucosaminic acid & - & - & + & - \\
\hline D-Alanine, D-glucose 6-phosphate & - & - & - & + \\
\hline
\end{tabular}


Table 3. Cellular fatty acid composition (\%) of the bacteria studied and reference strains

Strains: 1 , P. saccharophila CCUG $32988^{\mathrm{T}} ; 2$, P. puraquae CCUG $52769^{\mathrm{T}}$; 3, P. aquatica CCUG $52575^{\mathrm{T}}$; 4, M. chitosanitabida IAM $14711^{\mathrm{T}}$; 5, Roseateles depolymerans CCUG 52219 ${ }^{\mathrm{T}}$; 6, Roseateles depolymerans CCUG 52220; 7, strain CCUG 52222 ${ }^{\mathrm{T}}$ (Roseateles terrae sp. nov.); 8, strain CCUG $48205^{\mathrm{T}}$ (Roseateles aquatilis sp. nov.). - , Below the limit of detection.

\begin{tabular}{|lcccccccc|}
\hline Fatty acid & $\mathbf{1}$ & $\mathbf{2}$ & $\mathbf{3}$ & $\mathbf{4}$ & $\mathbf{5}$ & $\mathbf{6}$ & $\mathbf{7}$ & $\mathbf{8}$ \\
\hline $10: 03-\mathrm{OH}$ & 9.2 & 7.1 & 9.4 & 3.8 & 5.8 & 5.0 & 7.2 & 4.1 \\
$12: 0$ & 7.4 & 4.9 & 7.4 & - & 0.9 & 0.8 & 2.5 & - \\
$12: 02-\mathrm{OH}$ & 3.8 & 2.7 & 1.8 & 2.1 & 2.2 & 1.9 & 1.7 & 2.0 \\
$14: 0$ & 1.3 & 1.0 & 1.8 & 0.8 & 1.2 & 1.1 & 1.7 & 0.5 \\
$15: 0$ & 1.0 & 0.6 & 1.4 & 0.2 & 1.3 & 1.5 & - & 0.3 \\
$16: 0$ iso & - & - & - & - & - & 0.3 & - & - \\
$16: 1 \omega 7 c$ & 41.9 & 47.7 & 43.1 & 44.1 & 42.8 & 41.9 & 45.5 & 44.9 \\
$16: 0$ & 32.0 & 30.1 & 32.0 & 31.0 & 24.0 & 28.2 & 25.9 & 27.7 \\
$18: 2 \omega 6,9 c / 17: 0$ & - & - & - & - & 0.3 & 0.3 & - & - \\
$18: 1 \omega 9 c$ & - & - & - & - & 0.3 & 0.3 & - & - \\
$18: 1 \omega 7 c / 12 t / 9 t$ & 3.3 & 3.7 & 3.2 & 12.9 & 13.0 & 10.5 & 11.0 & 15.5 \\
$18: 0$ & - & 0.5 & - & 0.5 & 0.4 & 0.3 & - & 0.6 \\
Unidentified & - & - & - & - & 0.1 & 0.2 & - & 0.6 \\
& & & & & & & & \\
\hline
\end{tabular}

The 16S rRNA, internally transcribed spacer 1 (ITS1; between the $16 \mathrm{~S}$ and the $23 \mathrm{~S}$ genes), nifH (nitrogenase) and Rubisco genes were amplified from genomic DNA by PCR, and sequenced as described previously (Gomila et al., 2007). Gene sequences were aligned with the homologous sequences of the closest relatives retrieved using the BLAST analysis tool and the NCBI nucleotide sequence database. The alignments were done using a hierarchical method for multiple alignments implemented in the program CLUSTAL_X (Thompson et al., 1997). Automatically aligned sequences were checked manually. Sequence similarities and evolutionary distances were calculated with programs implemented in PHYLIP (Phylogeny Inference Package, version 3.5c) (Felsenstein, 1989). The $16 \mathrm{~S}$ rRNA gene sequence of strain CCUG 52220 was $99.7 \%$ similar to that of Roseateles depolymerans CCUG $52219^{\mathrm{T}}$ (Fig. 1). Strain CCUG $52222^{\mathrm{T}}$ clustered in the same phylogenetic branch of the 16S rRNA gene sequence tree, with a sequence similarity of $99.6 \%$ with that of the type strain, and was similar to the sequences of the species in the genus Pelomonas (between 97.2 and $97.9 \%$ ) and to the type strain of M. chitosanitabida (98.1\%). Strain CCUG $48205^{\mathrm{T}}$ also grouped in the Roseateles branch, with a similarity of $98.6 \%$ to the $16 \mathrm{~S}$ rRNA gene sequence of the type strain of Roseateles depolymerans (see Supplementary Table S3 in IJSEM Online). The type strain of Roseateles depolymerans, as well as strains CCUG 52220 and CCUG $52222^{\mathrm{T}}$, showed two ITS1 amplicons of different sizes and were not sequenced. Rubisco genes $c b b L$ of green or red form I enzymes and $c b b M$ of the form II enzyme did not amplify in any of the strains. The nifH genes in strains CCUG 52219 ${ }^{\mathrm{T}}$, CCUG 52220 and CCUG $52222^{\mathrm{T}}$ were
PCR-amplified and sequenced, and showed the same nucleotide sequence.

Amplification of the partial puf (photosynthetic) gene operon was done for the four Roseateles strains using primers pufLF ( $5^{\prime}$-CTKTTCGACTTCTGGGTSGG- $\left.3^{\prime}\right)$ and pufMR (5'-CCCATSGTCCAGCGCCAGAA-3'). The following PCR conditions were employed: an initial cycle at $94{ }^{\circ} \mathrm{C}$ for $4 \mathrm{~min}, 35$ cycles at $94{ }^{\circ} \mathrm{C}$ for $1 \mathrm{~min}, 56{ }^{\circ} \mathrm{C}$ for $1 \mathrm{~min}$ and $72{ }^{\circ} \mathrm{C}$ for $1.5 \mathrm{~min}$, and a final cycle at $72{ }^{\circ} \mathrm{C}$ for $10 \mathrm{~min}$. A fragment of about $1.5 \mathrm{~kb}$ in size was amplified for strains CCUG 52219 ${ }^{\mathrm{T}}$, CCUG 52220 and CCUG $52222^{\mathrm{T}}$. The PCR product was sequenced and compared with databases, confirming that photosynthetic genes are present in these strains. DNA of strain CCUG $48205^{\mathrm{T}}$ did not amplify. A Southern blot analysis was also performed with the four Roseateles strains by digestion of the genomic DNAs with the restriction enzymes ApaI and EcoRI (GE Health Care), followed by hybridization with the amplified puf gene fragment of strain CCUG $52219^{\mathrm{T}}$ as a probe. Strain CCUG $48205^{\mathrm{T}}$ did not hybridize with the probe, but the other three strains gave a positive signal (data not shown).

In addition to the phylogenetic, genomic and chemotaxonomic differences, strain CCUG $48205^{\mathrm{T}}$ could be differentiated from other Roseateles strains by its narrow range of temperatures for growth, by the assimilation of different carbon sources, catalase, $\beta$-glucosidase and $\beta$-galactosidase reactions and by the absence of nif and puf genes. Strain CCUG $52222^{\mathrm{T}}$ could be differentiated from Roseateles depolymerans by its profile of carbon sources assimilated and by the urease reaction.

Based on these results, we conclude that strain CCUG 52220 belongs to the species Roseateles depolymerans and that strains CCUG $48205^{\mathrm{T}}$ and CCUG $52222^{\mathrm{T}}$ represent two novel species, with the names Roseateles aquatilis sp. nov. and Roseateles terrae sp. nov., respectively.

\section{Emended description of the genus Roseateles Suyama et al. 1999}

Roseateles (Ro.se.a.te'les. L. adj. roseus rose-coloured, pink; Gr. adj. ateles defective, incomplete; N.L. masc. n. roseateles the rose-coloured incomplete photosynthetic bacterium).

Cells are motile, Gram-negative straight rods. Cells of some strains are pink in colour under conditions suitable for photosynthetic pigment production. Cis-9-hexadecanoic and hexadecanoic acids are the major cellular fatty acids. Low levels of dodecanoic acid and high levels of cis-11octadecanoic acid differentiate the genus from other genera in the same phylogenetic branch. Other characteristics of the genus are given by Suyama et al. (1999).

\section{Description of Roseateles aquatilis sp. nov.}

Roseateles aquatilis (a.qua.ti'lis. L. masc. adj. aquatilis aquatic, growing in water). 


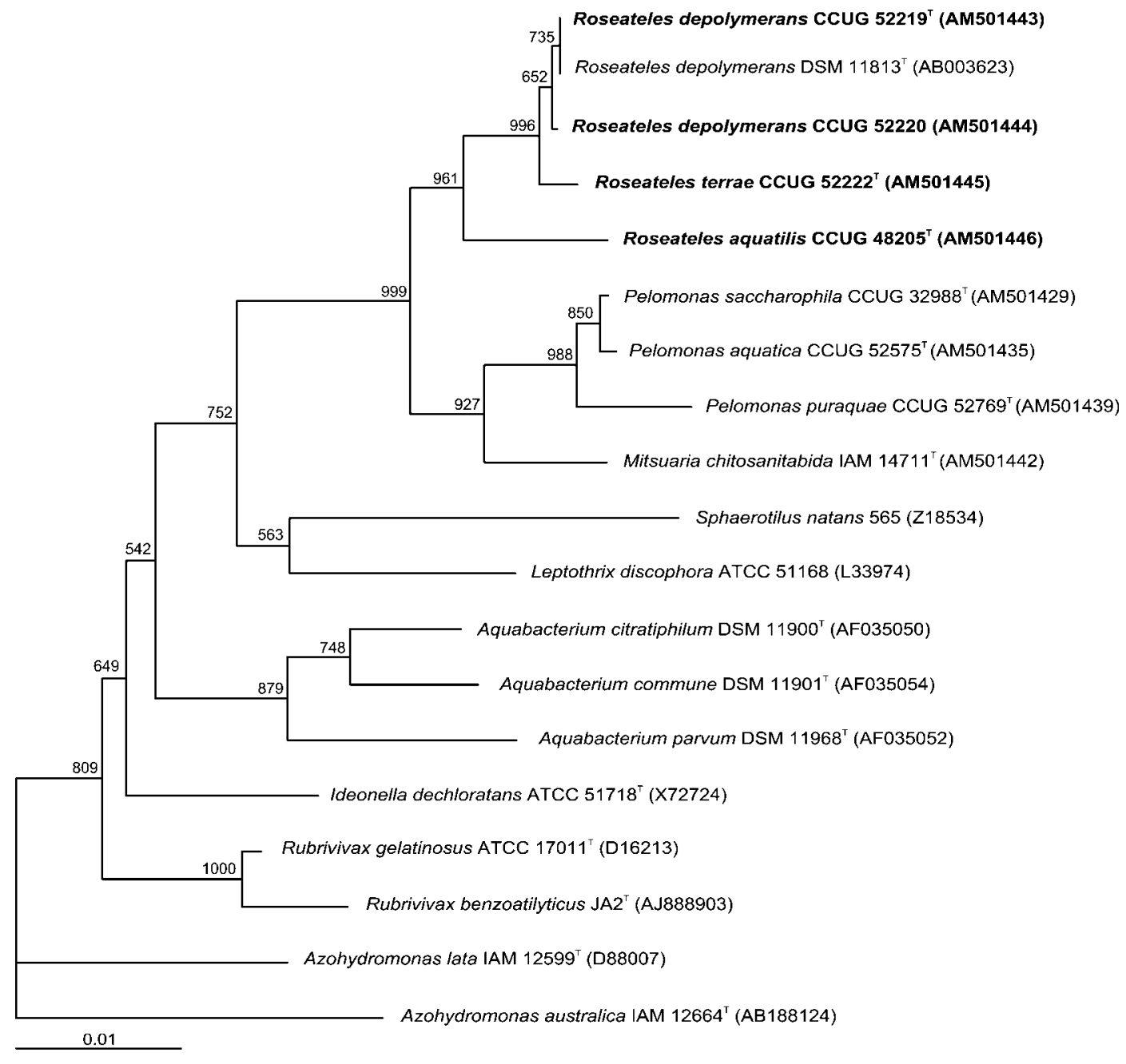

Fig. 1. Phylogenetic tree, based on $16 \mathrm{~S}$ rRNA gene sequence comparisons over 1380 aligned bases, showing the relationship between the genera Mitsuaria, Pelomonas and Roseateles in the Betaproteobacteria. The tree was constructed using the neighbour-joining method, following distance analysis calculated by using the Jukes and Cantor method (Jukes \& Cantor, 1969). The topology of the tree was visualized by means of the program TreeView (Page, 1996). Bootstrap values greater than 500 based on 1000 replications are indicated at nodes. Sequences indicated in bold were determined in this study. GenBank accession numbers are given in parentheses. Bar, 0.01 nucleotide substitutions per site.

Colonies are $4-6 \mathrm{~mm}$ in diameter, clear white, circular and umbonate, with an undulate margin and translucent. Fourday-old colonies show concentric circles. Non-pigmented. Oxidase-positive and catalase-negative. Growth occurs in R2A medium at $20-30{ }^{\circ} \mathrm{C}$, but not at 10 or $45{ }^{\circ} \mathrm{C}$. Cells are rod-shaped $(2 \mu \mathrm{m}$ in length and $0.5 \mu \mathrm{m}$ in width) with single polar flagella. Nitrate reduction, indole formation, glucose fermentation, arginine dihydrolase, urease, $\beta$-galactosidase (PNPG) and aesculin tests are negative. Gelatin hydrolysis is positive. D-Glucose, maltose, gluconate and malic acid are assimilated. L-Arabinose, D-mannose, D-mannitol, $\mathrm{N}$-acetyl-D-glucosamine, capric acid, adipic acid, citrate and phenylacetic acid are not assimilated. Photosynthetic genes (puf) are not detected.
The type strain, CCUG $48205^{\mathrm{T}} \quad\left(=\mathrm{CECT} 7248^{\mathrm{T}}\right)$, was isolated from industrial water in Sweden.

\section{Description of Roseateles terrae sp. nov.}

Roseateles terrae (ter'rae. L. gen. n. terrae of the soil).

Colonies are circular, $4-6 \mathrm{~mm}$ in diameter and convex, with an undulate transparent margin. Non-pigmented. Oxidase- and catalase-positive. Growth occurs in R2A medium at $10-37{ }^{\circ} \mathrm{C}$, but not at 4 or $45{ }^{\circ} \mathrm{C}$. Cells are rodshaped $(2 \mu \mathrm{m}$ in length and $0.5 \mu \mathrm{m}$ in width) with single polar flagella. Nitrate reduction, indole formation, glucose fermentation, arginine dihydrolase and urease tests are negative. $\beta$-Galactosidase (PNPG), aesculin and gelatin 
hydrolysis are positive. D-Glucose, L-arabinose, D-mannose, D-mannitol, maltose, gluconate and capric acid are assimilated. Assimilation of malic acid is extremely weak. $\mathrm{N}$-Acetyl-D-glucosamine, adipic acid, citrate and phenylacetic acid are not assimilated. Photosynthetic genes (puf) are detected, but are not expressed under the experimental conditions used.

The type strain, CCUG $52222^{\mathrm{T}}\left(=\mathrm{CECT} 7247^{\mathrm{T}}\right)$, was isolated from soil in Japan.

\section{Acknowledgements}

This work was supported in part by the CICYT (Spain) grant REN2002-04035-CO3-01 and by the 'I Plà Balear de Recerca I Desenvolupament Tecnològic de les Illes Balears'. M.G. was the recipient of a predoctoral fellowship from the Spanish Ministerio de Educación y Ciencia. We gratefully acknowledge the excellent technical assistance of Gertrud Stahlhut. Also thanks to Kent Molin for his excellent cellular fatty acid analysis and to Tetsushi Suyama for strain deposits. We thank J. Gascó for helpful discussions.

\section{References}

Amakata, D., Matsuo, Y., Shimono, K., Kweon Park, J., Soo Yun, C., Matsuda, H., Yokota, A. \& Kawamukai, M. (2005). Mitsuaria chitosanitabida gen. nov., sp. nov., an aerobic, chitosanase-producing member of the 'Betaproteobacteria'. Int J Syst Evol Microbiol 55, 1927-1932.

Aragno, M. \& Schlegel, H. G. (1992). The mesophilic hydrogenoxidizing (Knallgas) bacteria. In The Prokaryotes, vol. 1, pp. 344-384, 2nd edn. Edited by A. Balows, H. G. Trüper, M. Dworkin, W. Harder \& K. H. Schleifer. New York: Springer.

Cowan, S. T. (1974). Cowan and Steel's Manual for the Identification of Medical Bacteria, 2nd edn. London: Cambridge University Press.

Felsenstein, J. (1989). PHYLIP - phylogeny inference package (version 3.2). Cladistics 5, 164-166.

Gomila, M., Bowien, B., Falsen, E., Moore, E. R. B. \& Lalucat, J. (2007). Description of Pelomonas aquatica sp. nov. and Pelomonas puraquae sp. nov., isolated from industrial and haemodialysis water. Int J Syst Evol Microbiol 57, 2629-2635.

Jukes, T. H. \& Cantor, C. R. (1969). Evolution of protein molecules. In Mammalian Protein Metabolism, vol. 3, pp. 21-132. Edited by H. N. Munro. New York: Academic Press.

Kalmbach, S., Manz, W., Wecke, J. \& Szewzyk, U. (1999). Aquabacterium gen. nov., with description of Aquabacterium citratiphilum sp. nov., Aquabacterium parvum sp. nov. and Aquabacterium commune sp. nov., three in situ dominant bacterial species from the Berlin drinking water system. Int J Syst Bacteriol 49, 769-777.

Lalucat, J. (1988). Analysis of refractile (R) bodies. In Methods in Microbiology - Electron Microscopy in Microbiology, vol. 20, pp. 79-90. Edited by F. Mayer. London: Academic Press.
Malmqvist, A., Welander, T., Moore, E., Ternström, A., Molin, G. \& Stenström, I.-M. (1994). Ideonella dechloratans gen. nov., sp. nov., a new bacterium capable of growing anaerobically with chlorate as an electron acceptor. Syst Appl Microbiol 17, 58-64.

Marmur, J. (1961). A procedure for the isolation of deoxyribonucleic acid from microorganisms. J Mol Biol 3, 208-218.

Page, R. D. M. (1996). TreeView: an application to display phylogenetic trees on personal computers. Comput Appl Biosci 12, 357-358.

Reasoner, D. J. \& Geldreich, E. E. (1985). A new medium for the enumeration and subculture of bacteria from potable water. Appl Environ Microbiol 49, 1-7.

Spring, S. (2006). The genera Leptothrix and Sphaerotilus. In The Prokaryotes: a Handbook on the Biology of Bacteria, 3rd edn, vol. 5, pp. 758-777. Edited by M. Dworkin, S. Falkow, E. Rosenberg, K. H. Schleifer \& E. Stackebrandt. New York: Springer.

Suyama, T., Shigematsu, T., Takaichi, S., Nodasaka, Y., Fujikawa, S., Hosoya, H., Tokiwa, Y., Kanagawa, T. \& Hanada, S. (1999). Roseateles depolymerans gen. nov., sp. nov., a new bacteriochlorophyll $a$ containing obligate aerobe belonging to the $\beta$-subclass of the Proteobacteria. Int J Syst Bacteriol 49, 449-457.

Suyama, T., Shigematsu, T., Suzuki, T., Tokiwa, Y., Kanagawa, T., Nagashima, K. V. P. \& Hanada, S. (2002). Photosynthetic apparatus in Roseateles depolymerans 61A is transcriptionally induced by carbon limitation. Appl Environ Microbiol 68, 1665-1673.

Thompson, J. D., Gibson, T. J., Plewniak, F., Jeanmougin, F. \& Higgins, D. G. (1997). The CLUSTAL_X windows interface: flexible strategies for multiple sequence alignment aided by quality analysis tools. Nucleic Acids Res 25, 4876-4882.

Wen, A., Fegan, M., Hayward, C., Chakraborty, S. \& Sly, L. I. (1999). Phylogenetic relationships among members of the Comamonadaceae, and description of Delftia acidovorans (den Dooren de Jong 1926 and Tamaoka et al. 1987) gen. nov., comb. nov. Int J Syst Bacteriol 49, 567-576.

Willems, A. \& Gillis, M. (2005). Family IV. Comamonadaceae Willems, De Ley, Gillis and Kersters 1991a, 447 $7^{\mathrm{VP}}$. In Bergey's Manual of Systematic Bacteriology, 2nd edn. The Proteobacteria: The Alpha-, Beta-, Delta-, and Epsilonproteobacteria, vol. 2, part C, pp. 686-763. Edited by D. J. Brenner, N. R. Krieg, J. T. Staley \& G. M. Garrity. New York: Springer.

Willems, A., Gillis, M. \& De Ley, J. (1991). Transfer of Rhodocyclus gelatinosus to Rubrivivax gelatinosus gen. nov., comb. nov., and phylogenetic relationships with Leptothrix, Sphaerotilus natans, Pseudomonas saccharophila, and Alcaligenes latus. Int J Syst Bacteriol 41, 65-73.

Xie, C.-H. \& Yokota, A. (2005). Reclassification of Alcaligenes latus strains IAM $12599^{\mathrm{T}}$ and IAM 12664 and Pseudomonas saccharophila as Azohydromonas lata gen. nov., comb. nov., Azohydromonas australiaca sp. nov. and Pelomonas saccharophila gen. nov., comb. nov., respectively. Int J Syst Evol Microbiol 55, 2419-2425.

Ziemke, F., Höfle, M. G., Lalucat, J. \& Rosselló-Mora, R. (1998). Reclassification of Shewanella putrefaciens Owen's genomic group II as Shewanella baltica sp. nov. Int J Syst Bacteriol 48, 179-186. 